\title{
ANALISIS AKAD WAKALAH BIL UJRAH PADA JASA TITIP BELI ONLINE DALAM PRESPEKTIF KAIDAH FIKIH EKONOMI (Studi Kasus Pada Akun Instagram @jastiperopa777)
}

\author{
Siti Hasnaa Madinah, Putri Karunia Sari, Isnaini Rofiqoh \\ UIN Sunan Ampel Surabaya \\ sitihasnaamadinah@gmail.com
}

\begin{abstract}
Abstrak
Akad wakalah adalah akad pemberian kekuasaan oleh seseorang kepada orang lain untuk melakukan suatu yang bersyarat hukum, sedangkan pemberian kekuasaan itu sendiri bisa denggan mengggunakan dan atau tanpa pemberian upah. Pemberian upah pada akada wakalah inilah yang dinamaka sebagai wakalah bil ujrah. Sehingga, penelitian ini bertujuan untuk menganalisis dan mengetahui dari sudut pandang Kaidah fikih ekonomi terkait akad wakalah bil ujrah yang terdapat dalam transaksi jual jasa titip beli online. Dengan mengambil salah satu penyedia jasa titip beli online dalam sebuah aplikasi media social Instagram yaitu akun jastiperopa777 untuk di analisis kesesuaian akad wakalah bil ujrah dengan kaidah fikih ekonomi yang telah ada. Dalam analisis praktik transaksi pada akun ini telah mendekati kesesuaian pada Syarat Rukun yang ditetapkan berdasarkan akad Al-wakalah bil ujrah. Kaidah fikih yang terdapat didalamnya yaitu: (1) Segala sesuatu tergantung pada maksud niatnya, yang merupakan kaidah utama yang lima, dengan kaidah turunan, penentu dalam sebuah akad adalah tujuan dan hakekatnya, bukan lafadz dan bentuk kalimatnya. (2) Setiap perniagaan itu diatas saling ridho. (3)meringankan dan mempermudah bukan memberakan dan memepersulit. (4) pada dasarnya segala bentuk muamalah adalah boleh dilakukan kecuali ada dalil yang mengharamkannya. Karena pada dasarnya hukum suatu muamalat dibolehkan selagi tidak terdapat hal-hal yang menjadikan transaksi muamalat tersebut menjadi haram. dan mengandung banyak maslahat bagi umat.dengan pembahasan kasus ini kami juga akan menjabarkan kaidah fikih yang terdapat dalam akad transaksi ini, serta menganalisis bagaimana keabsahan dan eterkaitan antara transaksi kontemporer ini (Jasa titip beli online) dengan kaidah fikih ekonomi yang ada.
\end{abstract}

Kata Kunci: Jasa Titip Beli, Wakalah, Wakalah bil ujrah, Kaidah Fikih Ekonomi 


\section{PENDAHULUAN}

Islam merupakan agama yang kaffah (menyeluruh) memerikan pedoman pada segala aspek aktivitas manusia, mulai dari ibadah, akhlak, aqidah, muamalah, dan lainnya. Sebagai makhluk sosial, manusia dalam memenuhi kebutuhan hidupnya, selalu berinteraksi dan berhubungan antara individu satu dengan yang lain, baik secara spriritual maupun material, interaksi ini dinamakan sebagai hablum minnannas. Salah satu contoh interaksi antar individu manusia satu dengan yang lain contohnya dalam muamalah (bertransaksi), sehingga terdapat disiplin ilmu khusus bidang muamalah yang menjadi salah satu ajaran islam yang terpenting yaitu iqtishodiyah atau ekonomi Islam.

Syariat Islam dalam pembahasan problem muamalah lebih fokus untuk memberikan kaidah kaidah umum, pola pola kasus, dan prinsip-prinsip muamalah dari pada memeberikan bentuk dan jenis problema muamalah secara terperinci. ${ }^{1}$ Kegiatan muamalah hakikatnya ialah sesuatu yang merupakan syariat Allah untuk hambaNya dimana ia memudahkan dalam memenuhi kebutuhan sehari-hari, memunculkan rasa tolong menolong,

1 Indah Khoirotun Nisa, "Analisis Hukum Ekonomi Syariah Terhadap Praktek Aqad Jual Beli Online Dalam Sistem Go-Food”, (Skripsi-UIN Walisongi, Semarang, 2010), h.1. sehingga meringankan dalam aspek kebaikan dan membantu sesama. ${ }^{2}$

Praktik muamalah ditinjau dari berbgai aspek kegiatan transaksi bisnis akan bermunculan banyak macam kegiatan bisnis di era digital milenial ini. Berawal dari transaski mendapatkan barang dengan cara tukar menukar barang (barter), beranjak kepada jual beli di pasar dengan nilai tukar uang, kemudian saat ini yang sedang bersaing hebat dan merebah dikalangan masyarakat, yaitu jual beli dengan internet atau jual beli online. Disamping itu dampak persaingan dunia bisnis yang semakin tinggi dengan munculnya pelaku bisnis barang maupun jasa yang semakin bertambah namun tempat pemasaran yang semakin sempit, sehingga sikap konsumen dalam menentukan produk semakin selektif dan tawaran yang menarik dari para pelaku bisnis, mengakibatkan pelaku bisnis mulai melakukan inovasi dan semakini gencar dalam mempengaruhi konsumen untuk penjualannya melakukan keputusan pembelian. ${ }^{3}$

Pesatnya perkembangan teknologi modern telah banyak merubah dan memepengaruhi gaya hidup masyarakat, dimana mayoritas kegiatan manusia

\footnotetext{
2 Nomer 3 Zurifah Diana Sari, "Analisis Fiqih Muamalah terhadap Praktik Jasa Titip Beli Online dalam Akun Instagram @storemurmersby" (Skripsi-UIN sunan Ampel, Surabaya, 2018), h.2.

${ }^{3}$ Nomer 4 Devi Ernantika, "Analisis Fatwa DsnMui No. 113/Dsn-Mui/Ix/2017 Tentang Akad Wakalah Bi AlUjrah Terhadap Bisnis Personal Shopper/ Jastip Di Wilayah Ponorogo" (Skripsi-IAIN Ponorogo, 2019), h.2
} 
dapat dilakukan tanpa melakukan gerakan aktif, mulai dari bermain sosial media, permainan games, hanya dengan dirumah dan duduk di kantor menikmati layanan aplikasi, hingga belanja online, yang mana semua itu hanya membutuhkan perangkat telepon genggam atau laptop dengan jaringan internet sebagai media pendukung. Dan salah satu layanan aplikasi yang sedang marak layaknya jual beli online adalah layanan jasa titip beli online. ${ }^{4}$

Jasa titip beli online merupakan salah satu hal yang baru dalam hal muamalah kontemporer, dimana konsumen (penitip) meminta seorang yang sedang berada di suatu tempat dimana ia (penitip) ingin memenuhi kebutuhannya namun sulit untuk dengan sengaja mengadakan perjalanan ke tempat tersebut- sehingga ia dengan mudah mendapatkan barang tersebut, dan penitip memberi fee kepada yang wakilyang memebelikan. Jasa titip beli online adalah salah satu bisnis yang sedang banyak di gandrungi bukan hanya para traveler, namun semua mempunyai kesempatan untuk usaha jasa titip beli ini. Dengan tidak adanya modal yang harus dikeluarkan secara sengaja.

Jasa titip beli online memiliki kelebihan bagi konsumen pengguna jasa titip dimana ia tanpa harus mengeluarkan tenaga, biaya, dan tanpa

${ }^{4}$ Elisabeth Mustika Situmorang, " Perlindungan Hukum Terhadap Pengguana Jastip Onine" "(Skripsi--Universitas Sumatera Utara, 2019), h.1. melakukan perjalanan kesuatu tempat secara sengaja untuk mendapatkan produk yang ia inginkan. Dan kelebihan lainnya yang dapat diperoleh yaitu harga produk yang didapatkan dengan menggunakan jasa titip beli online dimana produk tersebut dibeli di tempat asal produk dibuat ini akan lebih efiisien dibandingkan dengan produk yang sama yang dijual di kota yang bukan tempat asal produk itu dibuat, serta original barang yang lebih terjamin keasliannya, dan kualitasnya mungkin lebih terjamin. ${ }^{5}$ Menjual jasa atau layanan kepada orang lain diperbolehkan dalam Islam. Seperti halnya jual beli barang dan komoditas. Terlebeih di era globalisasi ini dimana kebutuhan manusia semakin hari kian kompleks, maka kebutuhan akan jasa orang lain semakin banyak pula. ${ }^{6}$

Dalam tulisan ini kami mengambil studi kasus dari salah satu media sosial, yaitu instagram. Karena instagram disini memiliki eksistensi yang lebih tinggi diantara media sosial yang lain dalam dunia perbisnisan. Selain tampilannya yang lebih kompleks instagram lebih menonjolkan foto dan video daripada narasi sehingga lebih cocok dan menarik digunakan sebagai media pemasaran.

Dari banyaknya akun instagram yang membuka layanan jasa titip beli

\footnotetext{
5 Erwandi Tarmidzi, Harta Haram Muamalah Kontemporer, (Bogor: Berkat Mulia Insani, 2017)

6 Idri Shaffat, Hadis Ekonomi Hadis dalam Perspektif Hadis Nabi, (Jakarta: KENCANA, 2016), h. 82.
} 
online, kami mengambil salah satu akun jasa titip yang tujuan pemasarannya dari eropa ke indonesia, tepatnya di Berlin Jerman@yaitu@jastiperopa777. Pelayanan Jasa Titip beli online ini memiliki prosedur kerja yang sangat mudah dan sederhana. Posisi seorang penyedia layanan jastip beli online ini sebagai perantara atau pihak ketiga antara pembeli yaitu penitip dengan toko pemilik produk atau penjual, namun disisni ia memiliki tugas utama sebagai pembelanja bagi konsumen pengguna layanan jastip online ini. Pelaku jastip membuka layanan jastip online di mencarikan dan membelikan produk yang diinginkan konsumen penitip. ${ }^{7}$

\section{JASA TITIP BELI}

1) Pengertian Jasa titip beli

Dalam transaksi jual beli yang semakin berkembang pola mekanisme dan cara melakukan akad transaksinya, mulai dari hanya melakukan barter, kemudian berkembang menjadi transaksi jual beli menggunakan alat tukar uang, sehingga semakin berkembang dengan media online, juga menggunakan jasa dalam melakukan pembelian barang.

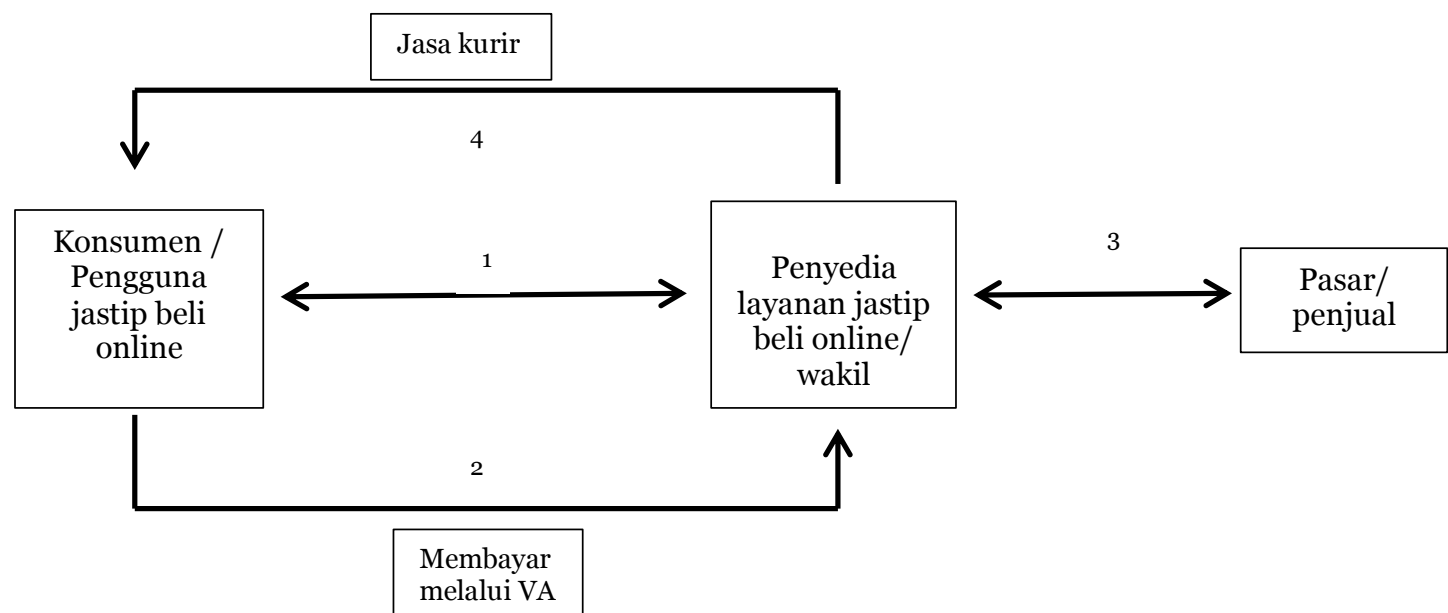

beberapa media sosial sebagai salah satu media promosi. Kemudian para konsumen menggunakan layanan jastip beli online tersebut untuk menjadikan wakilnya ia dalam mebelikan produk yang ia inginkan, ditempat itulah (media instagram) keduanya melakukan akad dan memulai transaksi dimana pelaku jastip akan membelikan produk yang disesuaikan dengan spesifikasi yang diberikan penitip dan kemudian diberikan fee atas jasanya yang berhasil

Merupakan sistem titip pembelanjaan untuk suatu barang yang ditawarkan oleh perorangan atau kelompok yang kemudian ditambahkan biaya imbalan atas jasa titip pembelanjaan yang biasa disebut ongkos jasa titip. ${ }^{8}$ Jasa titip beli terdapat dua keadaan, yaitu jasa titip beli

7 Devi Ernantika, "Analisis Fatwa Dsn-Mui No. 113/Dsn-Mui/Ix/2017 .......

8 Sa'adah, Hanafiah, Emelia Rizki Maulida, "Pola Akad Personal Shopper Dalam Jual Beli Online Di Kota Banjarmasin Kalimantan Selatan", Jurnal UIN Antasari Banjarmasin, 2019. 
secara face to face dan melalui platform media komunikasi atau jastip beli online, dimana tempat untuk melakukan transaksi dilakukan di media berbasis jaringan teknologi media komunikasi atau media sosial.

2) Mekanisme Jasa titip beli online

Jastip beli dalam transaksi di media online memiliki beberapa pihak yang ikut serta dalam memenuhi rukun jasa titip beli online, diantaranya adalah; Konsumen, penyedia jastip beli online (berupa platform marketplace atau media komunikasi sosial), penjual produk, jasa kurir antar barang, dan lembaga keuangan bank. Sehingga mekanisme transakasi jasa titip beli online ini akan dijelaskan pada bagan dibawah ini;

a. konsumen yang menginginkan membeli suatu produk di suatu tempat. Akan melakukan negosiasi transaksi dengan pelaku jastip beli online, seperti memberikan kuasa kepada pihak penyedia untuk membelikan barang dengan spesifikasi tertentu. Kemudian pihak jastip akan memberikan prosentase atau rumusan perhitungan yang akan menghasilkan total biaya yang harus dibayarkan oleh konsumen. Sehingga terjadi akad wakalh bil ujrah antar konsumen dengan pihak jastip.

b. Konsumen akan membayarkan biaya (biaya produk, fee, dan biaya lainnya) melalui virtual Account di salah satu lembaga keuangan (Transfer)

c. Setelah biaya sampai kepada pihak jastip maka akan segera di belikan produk yang diinginkan konsumen dengan spesifikasi yang diberikan. Jika produk yang di carikan atau titip belikan tidak tersedia dan pihak jastip tidak menemukan maka akan melakukan kesepakatan kembali.

$$
\text { d. Setelah barang }
$$

didapatkan maka pihak jastip akan segera diserahkan kepada konsumen dengan bantuan pengiriman jasa kurir. Dan barang akan sampai pada konsumen.

\section{AKAD WAKALAH BIL UJRAH}

\section{1) Definisi Wakalah bil ujrah}

Wakalah atau wakilah secara bahasa ialah perlindungan (Al-Hafidz), pencukupan (Al-Kifayah), tanggungan (Ad-Dhamman), atau pendelegasian (Attafwidh), yang diartikan juga dengan memberikan kuasa atau mewakilkan. ${ }^{9}$ Dalam fatwa DSN-MUI menyatakan Akad wakalah adalah akad pemberian kuasa dari muwakkil (الموكل) kepada wakil)(الوكيل) untuk melakukan perbuatan hukum tertentu. Sedangkan Wakalah bil ujrah adalah pemberian kuasa atau akad

9 Chindy Fransiska, et al, "Tinjauan Fiqih Muamalah Terhadap Fee dalam Praktik Jasa Titip Barang Online (Studi Kasus Pada Princessist Online Shop)", Jurnal Prosiding Kenangan dan Perbankan Syariah, (2019) 
wakalah dengan imbalan pemberian ujrah (fee). ${ }^{10}$

Sementara ujrah dalam pelaksanaan Wakalah adalah imbalan (fee) yang diberikan dari pihak yang diwakilkan kepada yang mewakilkan. Pemberian ujrah dalam wakalah tujuannya adalah untuk membalas kebaikan seseorang yang telah menolong dalam mewakilkan sesuatu pekerjaan atas jasa yang telah dikorbankan oleh orang yang menjadi wakil. ${ }^{11}$

2) Rukun dan Syarat

Rukun dan syarat ketentuan pada akad wakalah bil ujrah sesuai dengan fatwa dsn mui tentang akad wakalah bil ujrah, ${ }^{12}$ antara lain:

a. Muwakkil, yaitu pihak yang memberikan kuasa; dan wakil, yaitu pihak yang diberikan kuasa oleh muwakkil. Dengan syarat boleh berupa orang atau semisal dengan orang, seperti badan hukum ataupun tidak berbadan hukum, kedua pihak wajib cakap hukum sesuai dengan syariah dan uu yang berlaku. Muwakkil wajib mampu membayar ujrah dan memiliki kewenangan memberikan kuasa kepada pihak lain. Wakil wajib mampu melaksanakan tugas kuasa yang di wakilkan olehnya.

10 Fatwa DSN No. 113/DSN-MUI/IX/2017 tentang Akad Wakalah bil ujrah.

11 Chindy Fransiska, et al, "Tinjauan Fiqih Muamalah Terhadap Fee.....,

12 Fatwa DSN No. 113/DSN-MUI/IX/2017 tentang Akad Wakalab bil ujrah. b. Objek wakalah, dengan syarat hanya boleh dilakukan pada hal-hal yang boleh diwakalahkan, baik berupa perbuatan atau pekerjaan tertentu dan diketahui oleh wakildan muwakkil dengan jelas, serta harus bisa dilakukan oleh pihak wakil. Wakil boleh mewakilkan kembali kepada pihak lain atas suatu kuasa yang diterimananya dengan syarat dapat izin dari muwakkil, wakil juga tidak wajib menanggung resiko atas kerugian disebabkan perbuatan yang dilakukannya, kecuali karena alta'addi, al- taqshir, atau mukhalafat al- syurth.

c. Sighah, akad
wakalah bil ujrah harus dinyatakan dengan jelas dan tegas dimengerti kedua pihakyang berakad, baik secara tertulis, lisan, isyarat, dan perbuatan tindakan, juga dapat dilakukan dengan berbasis teknologi internet sesuai pedoman syariah dan hukum uu yang berlaku.

d. Ujrah, dapat berupa uang atau barang yang bisa digunakan nilai kemanfaatan barang tersebut, kuantitas atau kualitas ujrah harus jelas dan transparan dari segi prosentase, angka nominal, atau perhitungan yang disepakati dan diketahui 
oleh kedua belah pihak yang melakukan akad. ${ }^{13}$

3) Dalil wakalah bil ujrah

a. Dalil Al-Qur'an

Dalam Firman Allah swt,

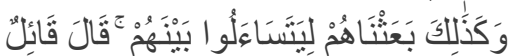

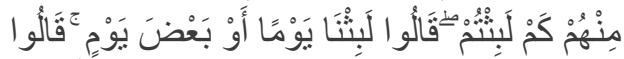

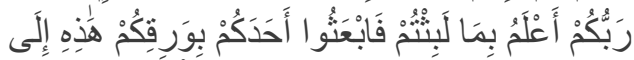

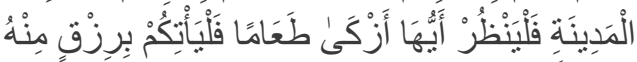

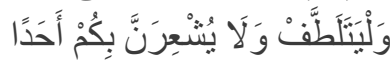

"Dan demikianlah Kami

bangunkan mereka, agar di antara mereka saling bertanya. Salah seorang di antara mereka berkata, 'sudah berapa lama kamu berada (disini)?' mereka menjawab, 'kita berada (disini) sehari atau setengah hari.' Berkata (yang lain lagi), 'Rabbmu lebih mengetahui berapa lama kamu berada (disini). Maka suruhlah salah seorang di antara kamu pergi kekota dengan membwa uang perakmu ini, dan hendaklah dia lihat manakah makanan yang lebih baik, dan bawalah sebagian makanan itu untukmu, dan hendaklah dia berlaku lemah lembut dan jangan sekali-kali menceritakan hal mu kepada siapa pun." 14

Ayat lain yang menjadi rujukan $a l$ wakalah adalah kisah tentang Nabi Yusuf Alaihissalam saat ia berkata kepada raja.

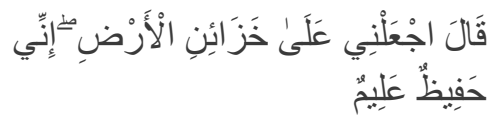

13 Ibid.

${ }^{14}$ Al-Qur'an, Surah Al-Kahfi (18) : 19
"Berkata Yusuf: 'Jadikanlah aku bendahrawan negara(Mesir); sesungguhnya aku adalah orang yang pandai menjaga, lagi berpengetahuan" "15

Dalam konteks ayat ini, Nabi Yusuf siap untuk menjadi wakil dan pengemban aman menjaga "federal Reserve" negeri Mesir ${ }^{16}$

b. Dalil al-Hadits

Hadits Rasulullah saw, dari 'Urwah

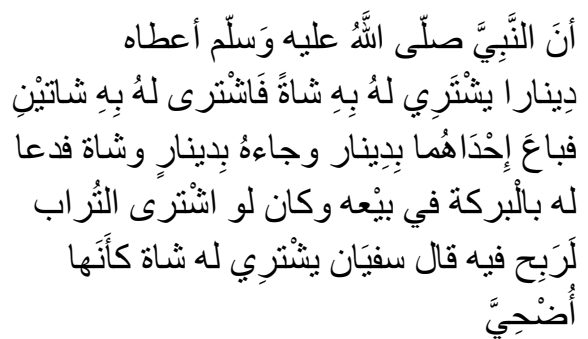

"Sesungguhnya Rasulullah Saw, memberinya satu dinar untuk dibelikan seekor kambing, kemudian ia membelinya untuk Nabi 2 kambing dengan uang berian tersebut. Maka ia jual satu ekor dengan harga satu dinar dan membawa satu ekor kambing dan satu dinar kepada Nabi saw. Lalu Beliau Saw mendoakannya dengan barokah: 'dia (Urwah), seandainya membeli debu pasti akan untung juga' Sufyan berkata: ' memebeli satu ekor kambing untuk Nabi,

\footnotetext{
15 Al- Quran, Surah Yusuf (12): 55

${ }^{16}$ Yudistia Teguh Ali, "WAKALAH (pemberian Kuasa)", Jurnal Ekonomi Islam, diakses dari academia.edu pada tanggal 13 september 2019
} 
terlihatnya untuk melakukan kurban."17

\section{c. Kaidah Fikih}

Dalam pembahsan kali ini kami mengambil beberpa kaidah fikih ekonomi yang berkaitan dengan akad wakalah bil ujrah ini yang termasuk kedalam akad yang baru dalam permasalahan muamakah kontemporer. Akad wakalah bil ujrah bisa didapatkan tiga kaidah turunan dari kaidah utama mengenai prinsip muamalah dengan jelas yaitu;

Kaidah Pertama, Penentu dalam sebuah akad bukan bentuk kalimatnya maupun lafadz pengucapan namun fokus pada tujuan dan hakekatnya dan merupakan salah satu cabang kaidah dari kaidah utama adalah,

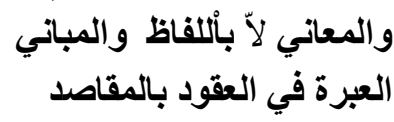

"Yang menjadi patokan dalam sebuah akad adalah tujuan dan hakekatnya, bukan lafadz dan bentuk kalimatnya." 18

Kaidah ini merupaka cabang dari kaidah utama yaitu Segala Perbuatan Tergantung Niatanya,

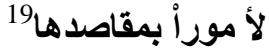

17 Al-Bukhari, al -Imam al-Hafidz Abi 'Abdillah ibn Isma'il, Shahibu-l-Bukhari, Beirut: Dar al fikr, 1995, h.322.

18 Muhammad Mushtafa az-Zuhaili, al-Qawaid alFiqhiyyah wa Tathbiqatuha fi al-Madzahib alArba'ah, (Damaskus: Dar al-Fikr, 1427H), juz 1, hlm. 403

19 Muhammad Hasan Abd. Ghafar, al-Qawaid alFiqhiyyah Bayna al-Asholah wa Tawjiih, diakses dari al-maktabah Syamilah al-Hadits [https://al-
Kaidah yang menyatakan bahwa semua perbuatan ataupun perkataan kembali pada niatnya. Dalil tentang kaidah ini diantaranya Firman Allah:
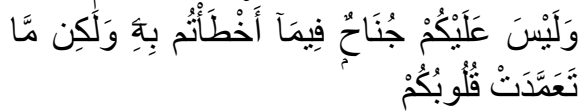

"Dan tidak ada dosa atasmu terhadap apa yang kamu khilaf padanya, tetapi (yang ada dosanya) apa yang disengaja oleh hatimu.,"20

Diantara dalil lain kaidah ini adalah sabda Nabi,

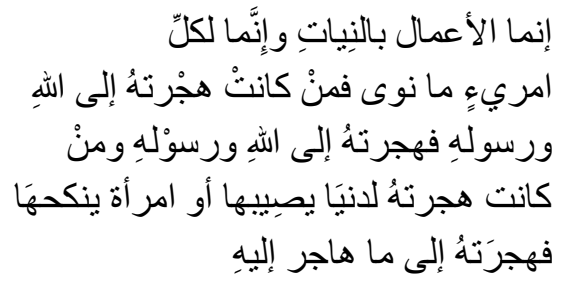

"Dari Amirul Mukmini Abu Hafsh Umar bin alKhaththab ra. Dia berkata, 'Saya pernah mendengar Rasulullah saw. bersabda, "Sesungguhnya amal-amal perbuatan itu tergantung niatnya, dan sesungguhnya untuk setiap orang hanyalah menurut apa yang diniatkan. Barangsiapa yang hijranya kepada Allah dan RasulNya, maka hijrahnya untuk Allah dan RasulNya, dan barangsiapa yang hijrahnya diniatkan untuk mendapatkan harta dunia atau untuk menkahi seorang wanita,

maktaba.org/book/32391/10\#p1] pada tgl 29 September 2019, hlm. 1

${ }^{20}$ Al-Qur'an, Surah Al-Ahzab(33): 5 
maka hijrahnya dinilai menurut niatnya. "21

Kaidah Kedua, pada dasarnya segala kegiatan muamalah itu diperbolehkan sampai datang dalil yang mengharamkannya, sebagaimana ulama membuat kaidah fikih,

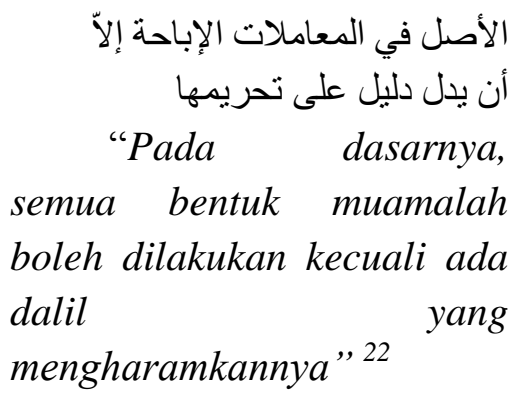

Aktivitas keduniaan (muamalah) pada dasarnya boleh dan asal hukumnya adalah jaiz atau boleh. Hukumnya akan berubah apabila datang larangan yang mengharamkannya. Apabila ada larangan, maka sesuatu yang halal akan berubah menjadi haram. apabila tidak ada larangan atau tidak ada dalil yang melarangnya, ia kembali kepada hukum asalnya, yaitu halal. Sebagaimana kebenaran Firman-Nya;

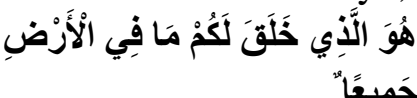

"Dialah Dzat yang menciptakan untuk kalian, semua yang ada di muka bumi ini. "23

21 Muhammad bin Shalih al-'Utsaimin, Syarhul Arba'in an-Nawawiyyah, cetakan ketiga, (Daar Tsuroyya Lin Nasyri, 2004M), hlm. 9

22 A. Djazuli, Kaidah-kaidah Fikih, (Jakarta: Pernada Media Group, 2007), 10

23 Al-Qur'an, Surah Al-Baqarah(2) : 29, Terjamahan oleh Departemen Agama RI, Al-

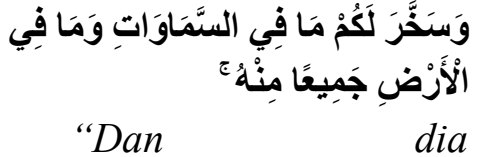

menundukkan apa yang ada di langit dan apa yang ada dibumi untukmu semuanya (sebagai rahmat) dariNya. "24

Allah menciptakan alam di dalamnya mengandung banyak sekali kekayaan yang bisa dimanfaatkan oleh manusia, dan Allah tidak mengharamkannya. Allah hanya mengharamkan beberapa bagian saja, sehingga daerah haram dalam agama sangat sempit dan wilayah halal sangat luas. Manusia sebagai makhluk Allah hanya bisa mengubah kekayaan tersebut menjadi barang kapital atau pemenuhan yang lain. Dan seluruh isi bumi, secara sengaja diciptakan oleh Allah untuk kepentingan dan kebutuhan manusia. Kegiatan muamalah tidak terbatas pada benda, namun mencakup perbuatan dan aktiitas yang tidak termasuk dalam ursan ibadah. Dalam muamalah, akal diberikan bagian yang lebih besar dengan syarat tidak boleh keluar dari batasan Al-Qur'an dan Hadits, pada pertimbangannya. $^{25}$

Qur'an dan Terjemah Special for Woman, (Bandung: Sygma Examedia Arkanleema, t.th), 5.

24 Ibid, ... Al-Jatsiyah(45) : 13, Terjamahan oleh Departemen Agama RI, Al-Qur'an dan Terjemah Special for Woman, (Bandung: Sygma Examedia Arkanleema, t.th), 499.

25 Idri Shaffat, Hadis Ekonomi Hadis dalam Perspektif Hadis Nabi, Jakarta: KENCANA, 2016), 82. 
عَنْ أَنَس: أَنَّ النَّبََّّ صَلَّى اللهُ عَلَيْهِ

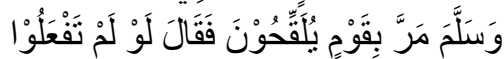

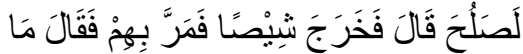

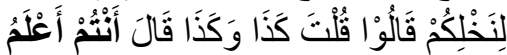

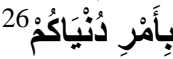

"Dari Anas ra. Bahwa Nabi

Saw. pernah melewati suatu

kaum yang sedang

mengawinkan pohon kurma

lalu beliau bersabda:

Sekiranya mereka tidak

melakukannya, kurma itu akan (tetap) baik. Tapi

setelah itu, ternyata kurma

tersebut tumbuh dalam

keadaan rusak. Hingga suatu

saat Nabi shallallahu 'alaihi

wasallam melewati mereka

lagi dan melihat hal itu

beliau bertanya: 'Adaapa

dengan pohon kurma kalian?

Mereka

menjawab;

Bukankah anda telah

mengatakan hal ini dan hal

itu? Beliau lalu bersabda:

'Kalian lebih mengetahui

urusan dunia kalian. ,,27

Para ulama juga sudah menyepakati tentang perniagaan adalah pekerjaan yang disepakati kebolehannya dan telah menjadi bagian dari syariat

26 al-Imam Abu Husain Muslim b. al-Hajjaj alQusayry al-Nisabury, Shabih Muslim No Hadis 2363/141, (Beirut, Lebanon: Dar al-Kutub alIlmiyah), 922

27 Terjemahan hadis oleh da'waright, Shabih Muslim, diakses dari https://imnasution.files.wordpress.com/2013/11 /shahih-muslim.pdf] pada tanggal 23 September 2019.
Islam. Setiap ulama yang menyusun dan menulis kitab hadits maun kitab fikih juga selalu melampirkan satu bab khusus yang memaparkan tentang pembahasan terkait aktivitas muamalah yang berangkat dari sumber-sumber dalil, hal tersebut menjadi salah satu bukti pentingnya pemahaman tentang muamalah. $^{28}$

Kaida Ketiga, asas 'an taradhin (suka sama suka), yaitu setiap bentuk tansaksi ekonomi antar-individu atau kelompok harus berdasarkan pada suka sama suka, tidak boleh ada pemaksaan, intimidasi, penipuan, tekanan, dan sebagainya.asas suka sama suka ini dimaksudkan agr tercipta stabilitas ekonomi individu ataupun masyarakat. ${ }^{29}$ Tidak sah jual beli jika salah seorang dari keduanya dipaksa tanpa suatu alasan yang benar. Seperti Firman Allah Ta'alaa:

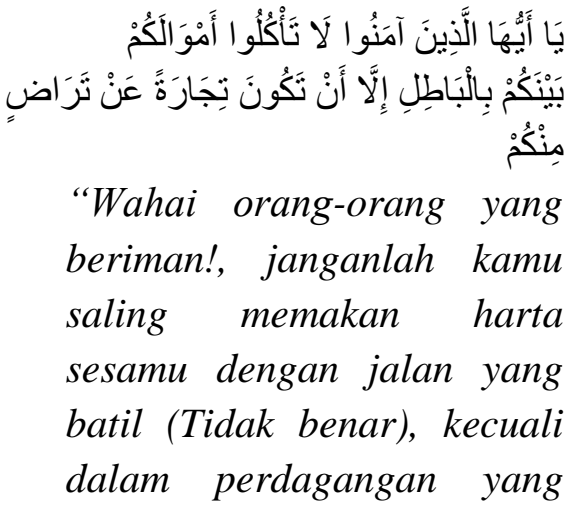

28 Muhammad Arifin Badri, "Prinsip Jual Beli dalam Ajaran Islam" pengusahamuslim.com, https://pengusahamuslim.com/1061-prinsip-jualbeli-dalam-ajaran-islam.html

${ }^{29}$ Idri Shaffat, Hadis......, 42. 
berlaku atas suka sama suka diantara kamu." 30

Para ulama mengambil kaidah fikih dalam ekonomi dari sabda Nabi Saw,

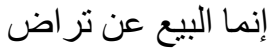

"Sesungguhnya Perniagaan itu hanyalah perniagaan yang didasari oleh rasa suka sama suka" 31

Dalam hal ini, tidak dibenarkan bagi siapapun memakan, mengambil, atau mengunakan harta saudaranya kecuali jika saudaranya benar-benar merelakan.Kerelaan diantara pihak yang berakad dianggap sebagai prasyarat bagi terwujudnya semua transaksi. Jika dalam transaksi tidak terpenuhi asas ini, maka sama dengan memakan sesuatu dengan cara yang bathil yang dilarang Allah dalam Firman-Nya Qur'an Surah AlBaqarah ayat 288. Perniagaan yang dilakukan belum dikatakan mencapai sebuah bentuk kegiatan yang saling rela diantara yang berakad hingga didalamnya tidak ada unsur paksaan, tekanan, tipuan, dan miss-statement. ${ }^{32}$

Kaidah keempat, meringankan dan mempermudah bukan memperberat dan

\footnotetext{
30 Al-Qur'an Surah an-Nisa(4) : 29, Terjamahan oleh Departemen Agama RI, Al-Qur'an dan Terjemah Special for Woman, (Bandung: Sygma Examedia Arkanleema, t.th), 83

31 Shalih b. Fauzan Abdullah al-Fauzan, AlMulakhkhash Al-Fiqhiy vol.2, (Riyadh: Dar alashima, $1423 \mathrm{H}), 9$.

32 Salehah Madjid, "Prinsip-prinsip (asas-asas) Muamalah", (Jurnal Hukum Ekonomi Syariah, 2018), vol.2(1), ISBN: 2549-4872.
}

mempersulit, sebagaimana ulama membuat kaidah,

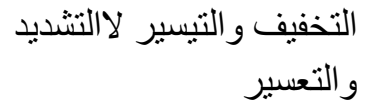

Artinya : "meringankan dan mempermudah bukan memperberat dan mempersulit".

4) Mekanisme wakalah bil ujrah

Akad wakalah bil ujrah termasuk dalam ijtihad baru dalam muamalah kontemporer dimana akad ini biasa ditemukan dalam lembaga keuangan bank. Pada lembaga perbankan, wakalah bil ujrah memiliki banyak produk salah satunya yang familiar adalah digunakan untuk transfer, dengan mekanisme akad wakalah bil ujrah pada transfer juga mewakili mekanisme akad ini pada umumnya yaitu sebagai berikut;

1. Nasabah memberikan amanat kuasa kepada bank, dimana nasabah ingin mengirimkan sejumlah uang kepada nasabah lainnya. Namun karena kendala jarak, maka digunakanlah bank sebagai wakil.

2. Bank penerima akan mengirim kliring nota, maksudnya salah satu badan hukum lembaga perbankan dibawah bank Indonesia akan mengkliringkan nota untuk di teruskan pada Bank Indonesia.

3. Bank Indonesia mengkreditkan rekening bank penerima.

4. Bank penerima mengkredirkan rekening penerima. 
5. Bank menetapkan fee atau imbalan kepada nasabah, upah jasa transfer pengiriman dikarenakan pembayaran atau

$$
\text { rekening nasabah. }
$$

Skema akad wakalah bil ujrah

3

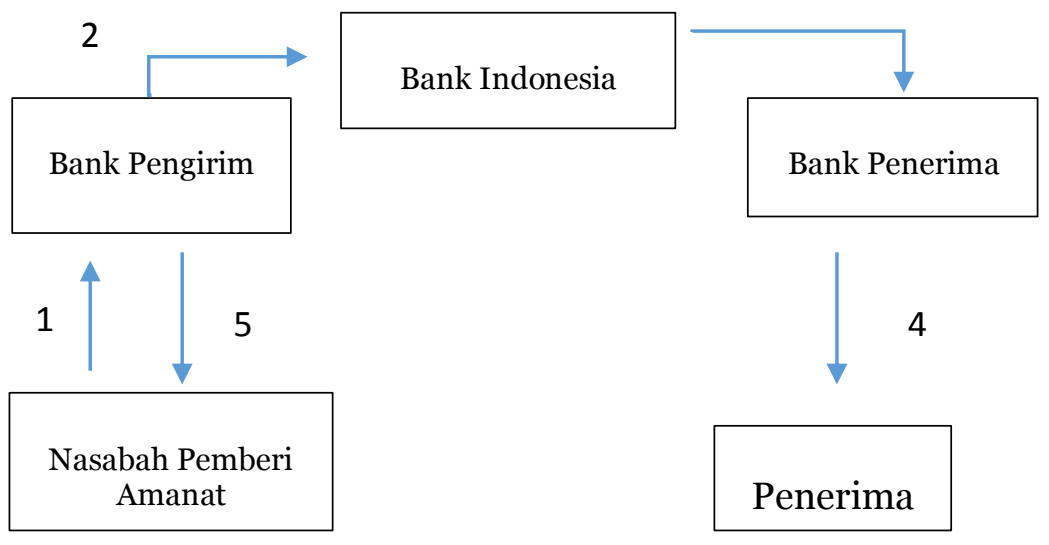

Profil Akun @jastiperopa777

1) Gambaran umum akun @jastiperopa777

Perkembangan dunia teknologi di era globalisasi yang begitu pesat menjadikan tuntutan kemajuan teknologi yang membuat tawaran berbagai fitur aplikasi jejaring sosial. Dalam dunia bisnis jejaring sosial digunakan untuk media promosi suatu produk yang jika diunggah akan banyak sekali yang melihat sihingga menjadi terkenal. Instagaram merupakan salah satu aplikasi media sosial yang berisi berbagai explore feed berupa gambar atau video milik kita atau milik orang lain dengan ditambahkan tulisan yang menjadi pendukung gambar. Lalu para pengguna akan dapat mengirim atau membagikan pada berbagai media sosial lainnya ${ }^{33}$

Akun instagram @jastiperopa777 yaitu salah satu dari banyaknya akun instagram penyedia layaanan jastip beli online. Akun instagram ini dikelola oleh ciciliaangelia dan tim-nya yang berdomisili di Negara Eropa terkhusus di daerah Jerman, yang bertugas melayani, mencarikan barang, membelikan, dan mengirimkannya pada konsumen yang menitip suatu produk. Latar belakang pembuatan akun ini kerena keterbatasan pada era dahulu si admin untuk mendapatkan barang yang

33 Zurifah Diana Sari, "ANALISIS FIQIH MUAMALAH TERHADAP PRAKTIK JASA TITIP BELI ONLINE DALAM AKUN INSTAGRAM@Storemurmersby" (Skripsi-UIN Sunan Ampel, Surabaya, 2018) 
diinginkan seperti yang telah dijelaskan. ${ }^{34}$

"Inget-inget jaman dulu kalau suka satu produk tapi negaranya jauh, yaudah abis 1 kali pakai, terus stop lamaa.. samapi misal kita balik lagi ke negara jauh itu baru bisa beli lagi. Tapi zaman sekarang serba jastip ini enak banget ya.. bisa nitip barang cross country dengan mudahnya ${ }^{, 35}$

2) Spesifikasi Jenis Produk

Pada feed akun instagram @jastiperopa777 telah dijelaskan beberapa informasi berkenaan dengan produk titipan, yaitu menerima semua jenis produk. Antara lain seperti produk makanan, kosmetik, produk bayi, berbagai macam bentuk fashion, tas, buku, mainan, dan sebagainya. Seperti yang publikasikan oleh admin akun ini

"Jadi ini bisa Jastip segala macam ya mulai makanan, skincare, books, mainan, branded stuffs, dan lainya. Dan pastinya harga jauh lebih murah daripada beli di Indo, 36

Produk titipan yang bisa di titip belikan adalah produk-produk barang dan merek asli negara di Eropa United Kingdom. Dimana produk tersebut jarang terdapat di Indonesia, jikalaupun ada maka harga-nya akan lebih mahal karena adanya tambahan untuk harga produk impor, transport kirim yang harus dikeluarkan dengan sengaja untuk mengadakan perjalanan antar negara,

34 Instagram@jastiperopa777, yang diakses pada 13 September 2019

35 Ibid, .... Highligh Q\&A

${ }^{36}$ Highligh Q\&A akun instagram @jastiperopa777 dan pajak oleh toko. Jika Jastip beli Online ini hanya mengeluarkan biaya produk, fee jasa, dan biaya pengeiriman dari jakarta menuju kota masing-masing.

3) Mekanisme Jasa Titip

Beli Online di Akun Instagram @jastiperopa777

Layanan jastip yang diterapkan pada akun instagram @jastiperopa777 memiliki mekanisme yang sangat mudah. Dengan titip belikan segala macam merek dan produk Original Europe UK secara online yang dibuka pemesanan setiap jangka waktu 2 minggu sekali. Setiap pembukaan Batch maka akan di informasikan di akun instagram tersebut. Alur praktis jasa titip beli online ini bisa dikatakan sangat sederhana dan mudah. Secara singkat dapat dijelaskan sebagai berikut;

a. Admin (peneyedia layanan jastip online) akun membuka Batch Pre Order jastip setiap 2 minggu sekali, sampai kuota titip beli terpenuhi.

b. Konsumen Penitip menghubungi admin melewati Direct Message (DM), Whattsapp, atau Line.

c. Konsumen penitip mengirimkan foto dan tipe detil gambar yang ingin di titip belikan. Bila memiliki informasi harga sendiri bisa memberitahu admin titip beli online.

d. Pemberitahuan informasi estimasi total harga kepada konsumen penitip, dimana harga total terdiri dari Harga barang asli 
di kalikan kurs yang berlaku, ditambah jastip fee, dan jasa antar barang dari jakarta menuju alamat konsumen penitip.

e. Jika setuju, deal, maka konsumen penitip men-transferkan pembayaran penuh ke rekening admin jasa titip beli online.

f. Tahap proses pesanana titipan oleh admin, admin jastip akan mencari dan membelikan barang titipbeli secara online atau di store yang ditentukan oleh admin.

g. Pemberitahuan oleh admin kepada konsumen penitip untuk barang titipan yang telah dibelikan, dan barang akan pada tahap packaging. Namun jika barang yang dipesan titip belikan tidak ada maka akan dilakukan pengembalian uang melalui rekening pemesan.

h. Barang tititpan konsumen akan di handcarry menuju Jakarta oleh tim admin yang pulang ke Indonesia, sesuai estimasi batch yang sudah ditentukan tanggal kedatangannya.

i. Tiba di Jakarta, barang akan dikirim menggunakan jasa kuriri antar barang (Tiki/Jne) menuju alamat pemesan jastip beli online. ${ }^{37}$

\section{ANALISIS AKAD WAKALAH BIL UJRAH PADA AKUN @JASTIPEROPA777}

Berdasarkan penjabaran mekanisme akad wakalah bil ujrah dan pola kerja pada akun jastip beli online ini, maka akan muncul beberapa kaidah fikih yang akan memperinci kelayakan dan kesesuaian mekanisme akad syariah ini. Kaidah Pertama, Hukum Asal Muamalah adalah Boleh. Menjual jasa atau layanan kepada orang lain diperbolehkan dalam Islam. Seperti halnya jual beli barang dan komoditas, penjualan jasa juga diperbolehkan dalam memenuhi kebutuhan manusia yang sebagai makhluk sosial dan makhluk ekonomi, manusia senantiasa membutuhkan jasa orang lain. Terlebeih di era globalisasi ini dimana kebutuhan manusia semakin hari kian kompleks, maka kebutuhan akan jasa orang lain semakin banyak pula. ${ }^{38}$

Diantara kegiatan muamalah yang diperbolehkan dalam syariat Islam adalah Wakalah bil ujrah berdasarkan ketatpan Majelis Ulama Indonesia yang telah dijabarkan di dalam bab pembahasan diatas, yang berangkat ari dalil-dalil Syari yaitu Al-Qur'an, Assunnah, dan kesepakan kaum muslimin, yang memberikan satu kaidah fikih ekonomi, yaitu terkait hukum asal dalam kegiatan muamalah adalah boleh dan halal hingga ada dalil yang

${ }^{38}$ Idri Shaffat, Hadis......., 218.
37 Akun Instagram@jastiperopa777,Highligh CARA JASTIP, 2019 
mengharamkan dan yang mengharamkan untuk dilakukan ${ }^{39}$.

Seteleh dilakukan analisis didapatkan hasil bahwa akad yang terkandung dalam transaksi jastip beli online pada akun @jastiperopa777 yaitu akad Wakalah dengan upah, yaitu penitip atau pembeli mewakilkan admin penyedia jasa titip beli online untuk mencarikan dan memebelikan produk yang diinginkan, dengan diberikan imbalan jasa sesuai dengan kesepakatan kedua belah pihak. Perniagaan melalui media online seperti jastip ini dalam pembahasan Islam telah disinggung yaitu dengan ijtihad para ulama yang memunculkan kaidah kaidah muamalah untuk memudahkan karakteristik peraturan akad wakalah. Wakalah merupakan akad antara dua pihak yang mana pihak satu menyerahkan, mendelegasikan, mewakilkan, atau memberikan mandat kepada pihak lain, dan pihak lain menjalankan amanat sesuai permintaan pihak yang mewakilkan. $^{40}$

Dalam ketetapan akad Wakalah mengenai penerapan dalam perniagaan jastip beli online terdapat konsep yang mendukung terciptanya akad wakalah bil ujrah yaitu akad pemberian kuasa (wakalah) dengan pemberian fee (ujrah), dimana konsumen penggunan layanan jastip sebagai pihak yang akan membeli produk keinginannya,

${ }^{39}$ Lihat Kaidah Fikih Muamalah pertama "al ashulu fii muamalaat al ibahab"

${ }^{40}$ Ismail, Perbankan Syariah, Jakarta: KENCANA, 2017), 200. meminta pihak penyedia jasa titip untuk mencari belikan produk yang diingikan, lalu proses akad wakalah telah terlaksana pihak jasstip akan melakukan tugas yang harus ditanggung jawabkan untuk mengadakan suatu produk yang inginkan konsumen, meminta imbalan yang disebut upah kepada pelanggan sebagai pihak yang diwakilkan admin jastip yang ketentuan akad Wakalah ini disebut dengan akad Wakalah Bi AlUjrah. ${ }^{41}$

Pelanggan (muwakil) akan memahami dan memberikan spesifikasi tertentu yang dilakukan sebagai wujud kegiatan transaksi dan pemenuhan khak wakil dengan pemberian upah kepadanya, yaitu akun @jastiperopa777. Pada akun ini pihak jastip beserta timnya akan melakukan sendiri untuk pencarian dan pengadaan produk tanpa mewakilkan kepada orang lain. Kemudian konsumen akan memberikan hak wakil, pihak jastip, yaitu pemberian upah bersamaan dengan pembayaran produk yang dibutuhkan. Wakil sebagai pihak yang diberikan kuasa akan berusaha dengan kemampuannya untuk mencarikan dan mengadakan produk yang diinginkan konsumen (muwakkil) selama penyediaan tersedia dan spesidikasi

41 Devi Ernantika, "Analisis Fatwa Dsn-Mui No. 113/Dsn-Mui/Ix/2017 Tentang Akad Wakalah Bi Al-Ujrah Terhadap Bisnis Personal Shopper/ Jastip Di Wilayah Ponorogo" (Skripsi--IAIN Ponorogo, 2019) diakses dari http:/ /etheses.iainponorogo.ac.id/6088/1/SKRI PSI \%20DEVI\%20ERNANTIKA.pdf] 
yang diminta ada. Namun, apabila pihak jastip tidak dapat mengadakan dan menemukan produk, maka aka nada pemberitahuan dan melakukan kesepakatan kembali anatar kedua pihak, dengan solusi dicarikan produk dengan spesifikasi lain atau membatalkan transaksi.

Kaidah Kedua, Penentu dalam Sebuah Akad adalah tujuan dan hakekatnya, bukan lafadz dan bentuk kalimatnya. Jasa titip beli online merupakan salah satu hal yang baru dalam hal muamalah kontemporer, dimana konsumen (penitip) meminta seorang yang sedang berada di suatu tempat -dimana ia (penitip) ingin memenuhi kebutuhannya namun sulit untuk dengan sengaja mengadakan perjalanan ke tempat tersebut- sehingga ia dengan mudah mendapatkan barang tersebut, dan penitip memberi fee kepada yang wakil yang memebelikan.

Dijelaskan mekanisme jastip beli online ini yaitu pihak Pertama (Penerima Jastip) dititip belikan barang keinginan pihak kedua (penitip). Maksud menitip disini bukanlah menitip barang (menggunakan akad wadi'ah) yang harus dijaga dan dikembalikan setiap waktu ketika penitip yang bersangkutan menghendaki. Namun, jasa titip disini maksudnya adalah memberikan mandat atau mewakilkan proses pembelian dengan atau tanpa imbalan, dimana mewakilakan disini artinya memberikan uang titip barang terlebih dahulu.
Dalam proses jastip online ini bentuknya murni jasa dan jual beli saja, hanya saja dalam pengucapannya adalah 'saya titip belikan barang A', maksudnya bukanlah menitip barang seperti lafadz pada umumnya, tetapi tujuannya adalah jasa dan jual beli. Sebagaiman dalam salah satu kaidah fikih yaitu yang menjadi patokan dalam sebuah akad adalah tujuan dan hakekatnya, bukan lafadz dan bentuk kalimatnya.

Kaidah Ketiga, Harus memenuhi , disetaiap akad jual beli. Dalam transaksi titip beli online ini harus ada saling ridha dalam setiap akad yang sifatnya perniagaan. Kaedah kedua ini memiliki prinsip suka sama suka yang menunjukkan bahwa segala bentuk aktivitas perniagaan tidak boleh dilakukan dengan paksaan, penipuan, kecurangan, intimidasi, dan praktikpraktik lain yang dapat menghilangkan kebebasan, kebenaran, dan kejujuran dalam transasksi ekonomi. Suka sama suka ( 'an taradhin) merupakan prinsip dasar dalam pembuatan akad pada kegiatan muamalah, baik pihak yang berakad, objek akad, dan harga. Dalam arti jika pada jual beli, penjual dan pembeli sepakat terhadap barang dan harga yang ditransaksikannya. ${ }^{42}$

Mekanisme dalam jasa titip beli online ini juga harus mengandung unsur saling ridha. Diantaranya saat pembeli atau pemesan meminta dibelikan barang disuatu negeri dengan

${ }^{42}$ Idri Shaffat, Hadis E....., 179. 
mengajukan akad, maka pihak yang dipesankan harus bersedia membelikan tanpa ada unsur paksaan dan tekanan dari pihak pembeli. Sehingga, bisa dikatakan tidak ada transaksi antara kedua belah pihak sampai tercapai kesepakatan. Orang yang terpaksa dalam melakukan transaksi ialah orang yang tidak bisa menolak dan dipojokkan dalam pengajuan akad, sehingga ia tidak mampu menolak dan terpaksa mencarikan dan membelikan barang tersebut. Misalnya, bila ia tidak berkenan membelikan maka ia terancam pencemaran nama baik dan terganggu. Dan paksaan disisni adalah tindakan yang ditekankan tanpa ada alasan yang dibenarkan dan jelas.

Dalam hal lain, seperti penetapan dalam nominal upah yang harus dibayar oleh penitip kepada pihak yang dititip beli kan barang. Setiap jasa titip beli online akan menetakan harga tarif kepada pembeli, dan menerangkan segala biaya total yang harus dikeluarkan dengan kesepakatan kedua belah pihak. Seperti, pada kaun instagram @jastiperopa777 akan mengenakan tarif biaya seluruhnya yang harus dibayar oleh penitip yang mencakup pertama, harga beli asli barang di tokonya dengan memberikan bukti pembelian atau melakukan Live shopping dengan perhitungan kurs mata uang yang berlaku dinegara penitip. Kedua, tarif fee jasa memebeliakan yang ditentukan oleh pihak yang dititip belikan. Menurut observasi testimoni dari pihak pembeli ialah wakil menarik fee sangat tipis dan kecil. Ketiga, tambahan ongkos kirim untuk pengiriman diluar kota si wakil.

Dari kesepakatan kedua belah pihak tersebut dengan ketentuanketentuan yang ditetapkan pihak jastip. Jika pemesan menyetujui maka akad terlakasana dan proses perwakilan akan dilaksanakan sesuai spesifikasi yang telah disepakati kedua belah pihak, hingga tersampainya barang tersebut kepada si pemesan.

Kaidah keempat, hadirnya transaksi jasa titip yang menggunakan media sosial sebagai media pemasaran ini sangat mempermudah konsumen ketika akan menggunakan jasanya, dimana konsumen tidak perlu dengan sengaja melakukan perjalanan ke lokasi hanya untuk membeli barang yang di inginkan. Sehingga konsumen bisa mendapatkan efisiensi untuk pengeluaran uang dan waktu mereka.

\section{PENUTUP}

Jasa titip beli online adalah salah satu hal yang baru dalam hal muamalah kontemporer, dimana konsumen (penitip) meminta seorang yang sedang berada di suatu tempat -dimana ia (penitip) ingin memenuhi kebutuhannya namun sulit untuk dengan sengaja mengadakan perjalanan ke tempat tersebut- sehingga ia dengan mudah mendapatkan barang tersebut, dan penitip memberi fee kepada yang wakil yang memebelikan. 
Dalam kasus jasa titip beli online mengandung beberapa kaidah fkih ekonomi yang dengannya transaksi ini masih boleh dilakukan selama tidak ada hal-hal yang membuatnya untuk tidak boleh dilakukan atau ada dalil yang mengharamkan atas transaksi ini. Pertama yaitu kaidah penentu dalam sebuah akad bukan bentuk kalimatnya maupun lafadz pengucapan namun fokus pada tujuan dan hakekatnya. Kaidah Kedua yaitu pada asalnya setiap muamalah adalah boleh. Ketiga kaidah fikih utama dalam ekonomi yang berbunyi "sesungguhnya setiap jual beli itu diatas saling ridha" dan kaidah terakhir adalah kaidah tentang harus saling memudahkan dan meringakan bukan memebratkan dan menyulitkan. Kaidah ini juga telah dikuat kan oleh sumber al-Qur'an dan Hadis.

Maka transaksi jasa tiitip beli online -wallahu a'alam- dibolehkan syariat Islam berdasarkan penjabaran kaidah diatas. Karena hukum awal suatu muamalah adalah boleh selam tidak terkandung didalamnya sebab-sebaba yang menjadikan transaksi muamalah itu berubah hukum menjadi haram dan mengandung banyak maslahat bagi beberapa kalangan yang merasa kesulitan untuk memenuhi kebutuhan hidupnya yang tidka bila dilakukan kecuali dengan banuan orang lain.

\section{DAFTAR PUSTAKA}

Al-Qur'an al-Karim;
Abd. Ghafar, Muhammad Hasan. alQawaid al-Fiqhiyyah Bayna al-Asholah wa Tawjiih, diakses dari al-maktabah Syamilah al-Hadits [https://almaktaba.org/book/32391/10\#p 1] pada tgl 29 September 2019.

Al-Bukhari, al -Imam al-Hafidz Abi 'Abdillah ibn Isma'il, Shahihu-lBukhari, Beirut: Dar al fikr, 1995, h.322.

Al-Fauzan, Shalih bin Fauzan bin Abdillah. Al-Mulakhkhash Al-Fiqhiy, vol.2. Riyadh: Dar al-ashima, $1423 \mathrm{H}$.

Al-Imam Abu Husain Muslim b. alHajjaj al-Qusayry al-Nisabury. Shahih Muslim No Hadis 2363/141. Beirut, Lebanon: Dar al-Kutub alIlmiyah.

Ali, Yudistia Teguh. "WAKALAH (pemberian Kuasa)". Jurnal Ekonomi Islam. diakses dari [academia.edu] pada tanggal 13 september 2019.

Al-'Utsaimin, Muhammad bin Shalih. Syarhul Arba'in an-Nawawiyyah. cetakan ketiga. Daar Tsuroyya Lin Nasyri, 2004M.

Az-Zuhaili, Muhammad Mushtafa. alQawaid al-Fiqhiyyah wa Tathbiqatuha fi alMadzahib alArba'ah, vol 1. Damaskus: Dar alFikr, 1427H.

Badri, Muhammad Arifin. "Prinsip Jual Beli dalam Ajaran Islam" pengusahamuslim.com, diakses dari [https://pengusahamuslim.com/1061prinsip-jual-beli-dalam-ajaranislam.html]. 
Djazuli, A. Kaidah-kaidah Fikih, Jakarta: Pernada Media Group, 2007. Departemen Agama RI, Al-Qur'an dan Terjemah Special for Woman, (Bandung: Sygma Examedia Arkanleema).

Ernantika, Devi. "Analisis Fatwa DsnMui No. 113/Dsn-Mui/Ix/2017 Tentang Akad WakaLah Bi Al-Ujrah Terhadap Bisnis Personal Shopper/ Jastip Di Wilayah Ponorogo". Skripsi-- IAIN Ponorogo, Ponorogo, 2019.

Fatwa DSN No. 113/DSN-MUI/IX/2017 tentang Akad Wakalah bil Ujrah.

Fransiska, Chindy et al. "Tinjauan Fiqih Muamalah Terhadap Fee dalam Praktik Jasa Titip Barang Online (Studi Kasus Pada Princessist Online Shop)". Jurnal Prosiding Keuangan dan Perbankan Syariah. 2019. diakses dari [http://karyailmiah.unisba.ac.id.]

Pada tanggal 13 Sepetember 2019.

Ismail. Perbankan Syariah. Jakarta: Kencana, 2017.

Madjid, Salehah. "Prinsip-prinsip (asasasas) Muamalah". Jurnal Hukum Ekonomi Syariah vol.2, No.1, 2018.

Nisa, Indah Khoirotum. "Analisis Hukum Ekonomi Syari'ah Terhadap Praktek Aqad Jual Beli Online Dalam Sistem Go-Food". Skripsi-UIN Walisongo, Semarang, 2018.

Sari, Zurifah Diana. Analisis Fiqih Muamalah Terhadap Praktik Jasa Titip Beli Online Dalam Akun Instagram @Storemurmersby”.
Skripsi-- UIN Sunan Ampel, Surabaya, 2018.

Shaffat, Idri. Hadis Ekonomi Hadis dalam Perspektif Hadis Nabi. Jakarta: Kencana, 2016.

Tarmizi, Erwandi. Harta Haram Muamalat Kontemporer. Jakarta: Berkat Mulia Insani, 2017. 